\title{
Translation of Tennesse Williams's The Night of the Iguana as a Novel and as a Play: A Descriptive Study
}

\author{
Nilüfer ALIMMEN* and Taha AKDAĞ ${ }^{* *}$
}

The aim of this study is to explore translation of theatre texts through a comparative analysis of two Turkish translations of the play The Night of the Iguana (1961) by Tennessee Williams: Iguananin Gecesi (1990) translated by Ülker İnce as a play and Iguana Gecesi (1966) translated by Canset Unan as a novel, both of which are interlingual translations. What makes the case of the two Turkish translations under scrutiny unique is that while Ince's translation is an intragenre translation, Unan's translation is an intergenre translation. In the study, both target texts have been analyzed in terms of the strategies employed by the translators with a focus on additions, omissions and transformation of tense. The results of the analysis discussed in the light of Skopos Theory have revealed that the main source of difference between the translation strategies deployed by the two translators is the shift of genre. Thus, it is argued that the different strategies used in the translations might be explained on the basis of the two different skopoi as manifest in the translation strategies examined. It is further claimed that the case illustrates how agents of translation might take the liberty of specifying their own translation skopos under the shaping influence of socio-historical, cultural and even economic circumstances of the target literary system.

Keywords: theatre translation; intragenre translation; intergenre translation; Tennessee Williams; The Night of the Iguana

\section{Introduction}

Translation of theatre texts has been widely debated by scholars. Since theatre texts have unique characteristics compared to other literary texts, many arguments have been pointed out by different scholars on translating them throughout the years. Taking these different points of view as a starting point, the present study ${ }^{1}$ analyzes two different Turkish translations of the play The Night of the Iguana $(1961)^{2}$ by Tennessee Williams. One of these translations is Iguananın Gecesi by Ülker İnce, published by Can Yayınları in 1990, which

\footnotetext{
*Assistant professor at Istanbul 29 May1s University.

E-mail: nalimen@29mayis.edu.tr; ORCID ID: https://orcid.org/0000-0002-1993-8918.

** Instructor at Düzce University.

E-mail: tahaakdag@duzce.edu.tr; ORCID ID: https://orcid.org/0000-0003-0107-8320.

(Received 14 August 2019; accepted 19 December 2019)

${ }^{1}$ Produced from Taha Akdağ's (2019) master's thesis submitted at Istanbul 29 Mayıs University under the supervision of Nilüfer Alimen.

${ }^{2}$ The Night of the Iguana was first published in 1961. The source text analyzed in the present study is the second print published in 1962 .
} 
transLogos 2019 Vol 2 Issue 2

Alimen, Nilüfer, and Taha Akdağ, pp. 159-179

Translation of Tennesse Williams's

A Translation Studies Journal

The Night of the Iguana as a Novel and as a

(C) Diye Global Communications Play: A Descriptive Study diye.com.tr|diye@diye.com.tr

was translated as a play. The translation by İnce was also put on the stage in Turkey in $2000 .^{3}$ The other translation is Iguana Gecesi by Canset Unan, published by Altın Kitaplar in 1966, which was translated as a novel.

\section{Translation of Theatre Texts}

Unlike stories or novels, theatre texts might be written and/or translated to be read and/or to be performed, which causes disagreement among scholars (cf. Karantay 1988; Karantay 1995; Demirkol 2006; Maral 2010; Haleva 2011; Bulut 2015; Bulut 2016; Vural Kara and Aslan 2015; Topçu 2017). In the context of intragenre translations of theatre texts (i.e., the translations of plays as plays without a genre shift), some scholars defend the idea that theatre texts cannot be separated from their performance dimension and should be translated in a performable way while others argue that translators should leave the performance dimension to directors, actors, etc. and treat the theatre text as if it were only a literary work. These two opposing modes of translation are respectively called "translation for the stage" and "translation for the page" (Minutella 2013, 44).

Scholars who argue that theatre texts should be translated for the stage claim that these texts involve paralinguistic components. Therefore, they argue that translation of a theatre text should be performable (i.e., the actors who are to perform the translated theatre text should find it easy to speak their lines and be able to act without rushing or lumbering). According to Patrice Pavis (1989), a theater semiotician originally, theatre translation is far more than translation of a dramatic text, and "real translation takes place on the level of the mise en scène as a whole." " In his view, just as one cannot define translation in general as a semantic equivalence of a source text, theatre translation is not an exception to this (41). In Theatre at the Crossroads of Culture, Pavis displays a series of concretizations (fig. 1) to explain the process of a theatre translation and claims that theatre translation involves factors related to stylistics, culture and fiction as well as linguistic ones.

\footnotetext{
3 İstanbul Devlet Tiyatrosu, “2000 Ekim Basın Bülteni” [October 2000 news release], news release, accessed August 12, 2019. http://archive.is/6Q8H.

${ }^{4}$ Unless otherwise stated, all emphases are in the originals.
} 
transLogos 2019 Vol 2 Issue 2

Alimen, Nilüfer, and Taha Akdağ, pp. 159-179

Translation of Tennesse Williams's

Figure 1. Pavis's series of concretizations in theatre translation $(2005,134)$

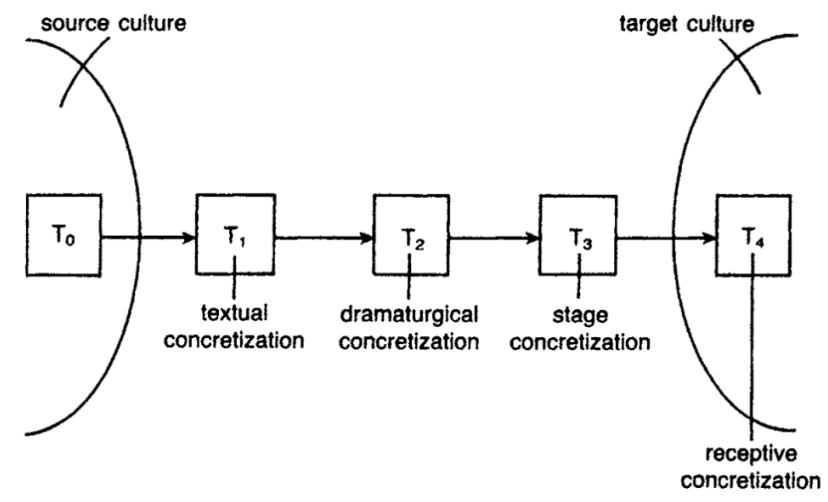

As seen in figure $1, \mathrm{~T}_{0}$ is the source text. The first concretization occurs in $\mathrm{T}_{1}$. In stage $\mathrm{T}_{1}$, translators are in the position of both a reader and a dramaturge. As a reader, they select among possible indications in the source text. Then they analyze the fiction in the text. They must think about rebuilding the plot and other theatrical features of the text (i.e., the characters, time and space, echoes, repetitions and responses) to make them suitable for the target culture. Stage $T_{2}$ consists of a coherent reading of both the plot and the spatiotemporal signs in the source text. The dramaturgical analysis in stage $T_{2}$ includes concretizing the text for it to be read and understood easily by the reader/spectator in the target culture and leading up to a future mise en scène. In stage $T_{3}$, the initially translated text in $T_{1}$ and $T_{2}$ is tested onstage before the audience in the target culture. The series ends in stage $\mathrm{T}_{4}$, where the text is concretized by the spectator after stage $T_{3}$. In stages $T_{1}$ and $T_{2}$, theatre translation is seen much more than a translation of a literary work. As Pavis claims, "translation is simultaneously a dramaturgical analysis $\left(\mathrm{T}_{1}\right.$ and $\left.\mathrm{T}_{2}\right)$, a mise en scène and a message to the audience" (136).

Another scholar who discusses the mode of translation for the stage is Ortrun Zuber. According to the scholar, there is almost no difference between drama and other literary genres in terms of the difficulties translators face in the translation process. However, she also points out that the translator of a drama must translate not only the meaning of a word or a sentence but also the implications, symbols of association, flow, imagery, tone and style. Comparing drama translation ${ }^{5}$ to other types of translation, she further claims that the translator of drama must take non-verbal and non-literary features into account more than the

\footnotetext{
${ }^{5}$ The terms 'theatre translation' and 'drama translation' are used interchangeably in the present study.
} 
transLogos 2019 Vol 2 Issue 2

Alimen, Nilüfer, and Taha Akdağ, pp. 159-179

Translation of Tennesse Williams's

translator of poetry or novels, and that plays are dependent on extra elements such as gestures, music, movements, speech rhythms, sound effects, stage scenery and lights (Zuber 1980, 92). Zuber ends her comparison between drama translation and other types of translation by emphasizing that the translator should "mentally direct, act and see the play at the same time," rather than translating solely the "words and their meanings" to produce a "speakable and performable" translation (93).

Scholars who argue that theatre texts should be translated for the page also accept the above-mentioned non-linguistic features of theatre texts; yet, they claim that these features should not affect the translation process. They suggest that translators do not have to have a background knowledge on theatre to translate a theatre text. Therefore, they need to work on it by ignoring the performance dimension and focusing on the text itself as if they were translating a short story or a novel. For instance, Susan Bassnett (1991) argues against the term 'performability,' which is considered as a key point in translation for the stage. She claims that the term does not have a proper definition, and this makes it a hiding place for the translators who make significant changes, including additions and omissions, in the translation process. She furthers her argument by stating that even if it has a definition, it will "vary, from culture to culture, from period to period and from text type to text type" (102). In her view, the written text is a prerequisite for the performable one, and the performance might change depending on the theatrical atmosphere. Thus, translators are suggested to leave the imaginary performable text aside and begin the translation process with the written text. After expressing the difference between the theatre texts and the texts written to be read only, Bassnett states that "theatre texts cannot be considered as identical to texts written to be read because the process of writing involves a consideration of the performance dimension, but neither can an abstract notion of performance be put before textual considerations" (110-111). According to Bassnett (1998), for theatre texts, the translator's task is not to make the text performable but to leave the solutions of inconsistencies to the director, the dramaturge, actors or someone else (105).

Franz H. Link (1980), addressing the translation of dramatic texts, asserts that "dramatic art has so far been considered as a mixed art, considering the dramatic text as literature and the production as a performing art," and one could see "the dramatic text as 
transLogos 2019 Vol 2 Issue 2

Alimen, Nilüfer, and Taha Akdağ, pp. 159-179

Translation of Tennesse Williams's

A Translation Studies Journal

The Night of the Iguana as a Novel and as a

Play: A Descriptive Study

(c) Diye Global Communications diye.com.tr|diye@diye.com.tr

literature only" (49). It can be understood that Link also believes that the translator can leave the performance dimension of a theatre text aside.

Unlike the above considerations, Berrin Aksoy (2002) highlights the co-existence of two different target audiences (i.e., readers and spectators) with different expectations from the same text. Hence, according to the author, the translator should consider both dimensions and produce a translation which is both to be read and to be staged (162).

\section{Translating for the Stage or for the Page in Intragenre Translations of Theatre Texts}

Different translation strategies are observed in different target texts translated from the same source text, depending on the mode of translation employed (i.e., "translation for the stage" or "translation for the page") (Minutella 2013, 44) as well as other factors. Vincenza Minutella argues that translations for the page have always included the full text, and a 'respectful' attitude emerged in translations for the page in the context of translating Shakespeare's Romeo and Juliet. She also points out that translators paid special attention to being 'faithful,' and they were sometimes criticized for being 'unfaithful' or 'unable to understand' the source text. As a reason for this, she states that in the twentieth century, the focus of the translators was to produce "uncut" translations (212). According to Minutella, "if translations are made for the page, the full text is translated, and there is an attempt to reproduce the source text fully" (214). When it comes to translation for the stage, Minutella asserts the opposite by noting that the need to be accepted in the target culture, target theatre system and to communicate to the target audience can lead the translator to employ different translation strategies (44-45). In other words, the 'faithful' attitude of translators turns into taking more 'liberties' with the source text, and therefore, "cuts" are tolerated for the translation ending up in the theatrical system (214).

In parallel with Minutella, Bassnett (2014) points out that translations for the page are common "where the commission is for publication rather than for stage production" (90), and omitting passages is one of the features of translation for the stage (91). According to the author, it can be deduced that translations for the stage "have tended away from notions of 'fidelity' to the source text" $(1991,106)$.

Max Beerbohm, Aylmer Maude and Bernard Shaw (1961) share their views on drama translation in a joint paper titled "Translating Drama: A Saturday Review Debate." Coming 
transLogos 2019 Vol 2 Issue 2

Alimen, Nilüfer, and Taha Akdağ, pp. 159-179

Translation of Tennesse Williams's

A Translation Studies Journal

The Night of the Iguana as a Novel and as a

Play: A Descriptive Study

(c) Diye Global Communications diye.com.tr|diye@diye.com.tr

up with a similar generalization to the one above, Beerbohm categorizes theatre translation as "the scientific way" and "the aesthetic way" (7). According to him, the scientific way is a translation for "library," and it requires translating with "fidelity" (7). It can be said that the scientific way can be replaced by translation for the page while the aesthetic way can be replaced by translation for the stage. Maude, on the other hand, argues that "[i]t would only be necessary to take certain liberties with the [original] text" when the translation is intended for the stage (9).

To summarize the approaches by different scholars, it can be said that translations for the page have been defined to tend to be "faithful" to the source text, and additions and omissions are not accepted in them while translations for the stage are away from the notion of "fidelity" as translators take more "liberties" with the source text and may employ strategies of addition and omission. However, the above-presented approaches are mainly centered on a discussion of intragenre theatre translation. Yet, what makes the case of the two Turkish translations under scrutiny in the present study unique is that while one of the translations was an intragenre translation, the other was an intergenre translation, which necessitates the consideration of genre shift in theatre translation.

\section{The Night of the Iguana in Turkish through Intergenre and Intragenre Translations}

"Paratexts" are defined by Gérard Genette (1997) as the products that "accompany" the published text (1). These products include titles, prefaces, covers, footnotes, endnotes, illustrations, etc. and play an important role in shaping the reader's approach to the text. Genette suggests that paratexts have the function of indicating the genre, and the titles might be paired with the indication of the genre such as "tragedy," "comedy" or "novel" (94-96). He emphasizes that a book is more likely to sell when it is labelled as a novel (97). The genre indication is usually seen on the cover or title page, at the beginning of the volume or at the end (99). A list of works by the same author (sometimes including the works "to be published," "in press," or "in preparation") or a list of series "dedicated to a specific genre" may also be provided (100-102). The paratextual elements indicating the genre are explored in this study to understand how the two target texts under discussion are presented to Turkish readers. 
transLogos 2019 Vol 2 Issue 2

Alimen, Nilüfer, and Taha Akdağ, pp. 159-179

Translation of Tennesse Williams's

A Translation Studies Journal

The Night of the Iguana as a Novel and as a

Play: A Descriptive Study

(C) Diye Global Communications diye.com.tr|diye@diye.com.tr

The title of Iguana Gecesi (1966), the intergenre translation, is not paired with a specific word indicating the genre. However, there are several indications in other paratextual elements showing that it is published as a novel. On the title page, it is stated that the book is published as the 76th book of the series titled "Meşhur Romanlar" (Famous novels) in March 1966. The title is introduced with the phrase: "Tennesse Williams'1n Filmi ve Kitabı Hâdise Yaratan Şaheseri," which informs the reader that "the book" and "the film" of this "masterpiece" by Williams "caused sensation." Following the title page, publication information (the name of the translator, illustrator, printing house, etc.) is given. At the top of the same page, it is explained that The Night of the Iguana has sold many copies and has been adapted into a film in which Ava Gardner, Richard Burton and Sue Lyon starred.

In the preface written by the publishing house titled "Iguana Gecesi ve Tennessee Williams" (The night of the iguana and Tennessee Williams), Williams is described as "the most powerful contemporary American playwright" (5). The publishing house states that Williams's works, such as A Streetcar Named Desire, Cat on a Hot Tin Roof and The Roman Spring of Mrs. Stone, were screened in Turkish movie theatres, and announces that the film version of the book will also be screened in Turkey in the future (6). The Night of The Iguana, the film adaptation, was directed by John Huston and premiered in 1964 in the United States of America. According to the Internet Movie Database (IMDb) website, it was screened with the title Ateşli Geceler in March 1968 in Turkey. ${ }^{6}$

The last 16 pages of the book are dedicated to promoting other publications, mostly novels. One of the books promoted by the publishing house is the Turkish translation of $M y$ Fair Lady by Bernard Shaw, titled Bir Kadın Yarattım. It is stated that Bir Kadın Yarattım is the first book of the series "Tiyatro Şaheserleri" (Masterpieces of the theatre). It is explained that Bernard's play is "adapted by" Alan Jay Lerner into a novel, and Lerner's adaptation is translated into Turkish by Unan. This makes the case of Iguana Gecesi (1966) even more interesting since the publishing house might be trying to conceal that it is the translation of a play. In conclusion, the only indication that the genre of the source text might be a play is the fact that Williams is presented as a "playwright" in the preface. However, other paratextual elements indicate otherwise. Considering that it was published under the series called

\footnotetext{
${ }^{6} \mathrm{IMDb}$ 's page for Ateşli Geceler, accessed $\quad$ August $12, \quad 2019$, https://www.imdb.com/title/tt0058404/releaseinfo?ref_=tt_ov_inf.
} 
transLogos 2019 Vol 2 Issue 2

Alimen, Nilüfer, and Taha Akdağ, pp. 159-179

Translation of Tennesse Williams's

"Famous Novels" instead of the other series dedicated to theatre texts, it is possible to label Iguana Gecesi (1966) as a novel on the basis of the analysis of paratexts.

The difference between the literary genres of Iguana Gecesi (1966), as the Turkish translation, and The Night of the Iguana, as the source text, is not explicitly stated in the cover or preface of the target text. To obtain information on the translation first-hand, a thorough research was also carried out. However, there is no personal information about Unan, and she is only mentioned as a translator on the Internet. ${ }^{7}$ According to the information provided by the publishing house (i.e., Altın Kitaplar), there has been no record of the source text or the translator since it was published back in 1966. A research was also carried out to find out if there is a novel version of the play in English by Williams or by someone else. However, there was no record of such book in the online catalogues of libraries. Then the publishing house of the source text (i.e., New Directions) was contacted, and they said that they did not hold a novel version of the book in their records. No information about the novel version of The Night of the Iguana was apparent in any of the books on the life and works of Williams. However, there is a short story written by Williams in 1948 with the same title as the play. A comparison between the source play and the short story version of The Night of the Iguana and the translated novel Iguana Gecesi (1966) was made. Just a few similarities were observed between the short story and the play. It is possible to say that there are differences in terms of characters and the plot. Unan's translation is also different from the short story.

On the other hand, İnce's translation, İuananın Gecesi, is presented as a translation of a play to the readers. On the cover page, it is stated that the book is published under the series titled "Çağdaş Drama Dizisi" (Contemporary drama series). In addition to this, there is a preface written by İnce regarding her thoughts on the play. It should also be noted that there is no mention of the short story the play is based on, or a novel version in İnce's preface.

\subsection{From a Play into a Novel: Intergenre Translation}

In the years when Translation Studies was still considered as a sub-discipline of Linguistics, there were scholars intentionally or unintentionally helping it make its way towards an independent discipline. One of those was Roman Jakobson, who was a linguist

\footnotetext{
${ }^{7}$ Müfit Özdeş, a distant relative of Unan, said that she passed away in the mid-1970s, and she translated books for Altın Kitaplar, Kelebek and some other publishing houses. He added that no close relatives of hers are alive.
} 
transLogos 2019 Vol 2 Issue 2

Alimen, Nilüfer, and Taha Akdağ, pp. 159-179

Translation of Tennesse Williams's

A Translation Studies Journal

The Night of the Iguana as a Novel and as a

Play: A Descriptive Study

(C) Diye Global Communications diye.com.tr|diye@diye.com.tr

and literary theorist. Jakobson ([1959] 2004) points out that "the meaning of any linguistic sign is its translation into some further, alternative sign" (232) and adds that this sign would be the more developed one. According to Jakobson, there are "three ways of interpreting a verbal sign: it may be translated into other signs of the same language, into another language or into another, nonverbal system of symbols." These three types of translation labelled by him are as follows:

1) Intralingual translation or rewording is an interpretation of verbal signs by means of other signs of the same language.

2) Interlingual translation or translation proper is an interpretation of verbal signs by means of some other language.

3) Intersemiotic translation or transmutation is an interpretation of verbal signs by means of signs of nonverbal sign systems. (233)

When a foreign theatre text is translated, it is called an "interlingual translation" but when that translation is put on the stage, that can be called as an "intersemiotic translation" since some parts of that translation are translated via non-verbal elements such as mimics, gestures and scenery. Therefore, a theatre translation has an intersemiotic nature only when it is to be performed. Thus, one might conclude that translators producing a "translation for the page" conduct an interlingual or intralingual translation. In this case, translators might disregard the intersemiotic nature of theatre translation. On the other hand, translators who employ "translation for the stage" mode might be more likely to take extra-linguistic factors into consideration and therefore produce an intersemiotic translation as well.

In the case of a shift of genre in translations, the produced text and the act of translation can be called as "intergenre translation." There are other names used for this particular type of translation such as "inter-genre translation" (Sionis 2000), "intergenres adaptation" (Bulut 2015) and "cross-genre translation" (Meyer 2009). Sionis (2000) uses the term "inter-genre translation" for discussing "genres of representation" (i.e., a written paper, a discussion, an oral paper) (1). Bulut (2015) examines translation of Reşat Nuri Gültekin's novel Çalıkuşu into a play by Necati Cumalı, which is a case of both intralingual and intergenre translation and uses the term "intergenres adaptation." Meyer (2009) investigates the translation of Richard Wagner's libretti into illustration by Franz Stassen. It is described as a case of "intersemiotic transmutation," which includes a shift of both medium and genre,

\footnotetext{
${ }^{8}$ For a comprehensive discussion on the perception of adaptation and translation in the context of theatre translation in the Turkish literary tradition, see Bulut 2016.
} 
transLogos 2019 Vol 2 Issue 2

Alimen, Nilüfer, and Taha Akdağ, pp. 159-179

Translation of Tennesse Williams's

A Translation Studies Journal

The Night of the Iguana as a Novel and as a

Play: A Descriptive Study

(c) Diye Global Communications diye.com.tr|diye@diye.com.tr

called as "cross-genre translation" (13). Eugenia Loffredo and Manuela Perteghella (2009) use the term "intergenre translation" for the interlingual translations of the poem "Les Fenêtres" (The windows) by Guillaume Apollinaire into lyrical prose. In the present study, the term "intergenre translation" is used by referring to Loffredo and Perteghella considering that their definition involves a shift of both genre and language between the source text and the target text, which is also the case in Unan's translation. Therefore, Unan's translation Iguana Gecesi can be defined as an 'interlingual intergenre translation' while İnce's translation İuananın Gecesi can be defined as an 'interlingual intragenre translation.'

\section{Translation Strategies Employed by the Translators of The Night of the Iguana}

Before the analysis of translation strategies, a brief summary of the play will be given. The setting of The Night of the Iguana is Costa Verde Hotel near Acapulco in Mexico. Shannon (an expelled minister and works as a tour guide), one of his old friends, the owner of the hotel, Maxine, Nonno (an old poet trying to finish his last poem before dying) and his granddaughter Hannah (a young girl who looks after her grandfather and has never felt love in her life) are the main characters in the play. Shannon wants the tourists to stay at the hotel because he is afraid of losing his job for he had sexual intercourse with one of the tourists in the tour. Maxine, whose husband has recently died, has nowhere to go and feels in need of being loved. They all feel trapped in life, and all of them are in search of something. There is also an iguana captured by the hotel staff. All the characters and the iguana spend the night with a desire to be and feel free or to be happy for achieving what they desire.

The strategies employed by the two translators of The Night of the Iguana have been analyzed in the present study with a focus on omissions, additions and transformation of tense, and the findings of the study are categorized accordingly. The particular excerpts from the source text (ST) and the target texts by İnce and Unan, which are respectively named as target text 1 (TT 1) and target text 2 (TT 2), are presented in the tables below.

\subsection{Additions}

In the analysis, it was observed that Unan made additions stemming from the genre shift in her translation. One of the examples of addition strategy, employed by Unan, is shown in table 1. 
transLogos 2019 Vol 2 Issue 2

Alimen, Nilüfer, and Taha Akdağ, pp. 159-179

Translation of Tennesse Williams's

A Translation Studies Journa

The Night of the Iguana as a Novel and as a

Play: A Descriptive Study

(C) Diye Global Communications diye.com.tr|diye@diye.com.tr

Table 1. Additions in Iguana Gecesi - 1

\section{ST - The Night of the Iguana (Author: Williams, 1962)}

With a soft intake of breath, she extends a hand before his mouth to see if he is still breathing. He isn't. (127)

\section{TT 1 - İguananın Gecesi (Translator: İnce, 1990)}

HANNAH hafifçe soluk alarak, hâlâ soluk alıp almadığını anlamak için elini NONNO'nun ağzına uzatır, almıyordur. (132)

(Breathing softly, HANNAH extends her hand before NONNO'S mouth to see if he is still breathing, he isn't. $)^{9}$

\section{TT 2 - İguana Gecesi (Translator: Unan, 1966)}

Hafiften bir nefes duyuldu, Hannah, elini, ihtiyarın ağzına yaklaştırdı. Böylelikle nefes alıp almadığını kontrol etmek istemiști. Hayır artık Nonno nefes almıyordu. Sessizce bu dünyadan çekilmişti. Fakat son dakikalarını mutlu olarak geçirmiş̧i ya. İnsanlar için de önemli olan tek şey, buydu zaten. Ölüm, her kulun borcuydu ama bir de mutlu olarak; gayesine kavuşmuş olarak ölmek vardır. Ölümlerin en güzeliydi bu... Hannah, çılgına dönmüştü. Onun ölümüne kendini inandırmak istemiyordu. Ama o soğumağa başlayan eller, o hareketsiz vücut, o moraran dudaklar, acı gerçekten kaçamazsın diye haykırıyorlardı adeta... Evet, insanlar ancak bir devreye kadar kendilerini aldatabilirdi ama sonra... işte ölüm, böylece her gerçeği ortaya koyardı birden... (155)

(A gentle breath was heard, Hannah extended her hand before the old man's mouth. Doing so, she wanted to check whether he was breathing. No, Nonno wasn't breathing anymore. He had departed from this world quietly. But he had spent his final moments happily. This was the only thing that mattered to people. Death was the debt of each human being, but dying happily, having achieved one's goal is another thing. It was the best of way of dying... Hannah went mad. She didn't want to believe that he was dead. But the hands that started cooling, the frozen body, the bruised lips were screaming that it was impossible to escape the grim reality... Yes, people would deceive themselves only to a certain extent, but then... death would suddenly reveal each and every reality...)

The excerpt above is the last stage direction in the play. Nonno, Hannah's grandfather, dies after he finishes his last poem. Nonno's death is implied by stating that he stopped breathing. It is seen that İnce did not make any additions while Unan added a part about how Hannah felt about her grandfather's death. In her translation, Unan explicitly tells the reader about his death by stating that his hands started to get cold, his body is motionless, and his lips turned purple. Unan, the translator, deduces that Nonno died happily for he finished his last poem. However, no such information is given in the source text.

\footnotetext{
${ }^{9}$ Back translations belong to the authors unless otherwise stated.
} 
transLogos 2019 Vol 2 Issue 2

Alimen, Nilüfer, and Taha Akdağ, pp. 159-179

Translation of Tennesse Williams's

Table 2. Additions in Iguana Gecesi - 2

\section{ST - The Night of the Iguana (Author: Williams, 1962)}

MISS FELLOWES [approaching]: Charlotte, Charlotte, Charlie!

CHARLOTTE: Help me and let me help you!

SHANNON: The helpless can't help the helpless! (50)

TT 1 - İguananın Gecesi (Translator: İnce, 1990)

FELLOWES: (Yaklaşarak) Charlotte! Charlotte! Charlie!

CHARLOTTE: Bana yardım et, ben de sana yardım edeyim!

SHANNON: Çaresizler çaresizlere yardım edemez! (56)

(FELLOWES: (Approaching) Charlotte! Charlotte! Charlie!

CHARLOTTE: Help me and let me help you!

SHANNON: The helpless can't help the helpless!)

\section{TT 2 - Iguana Gecesi (Translator: Unan, 1966)}

"Larry, sana yardım edeyim. Ne olur."

Miss Fellowes gittikçe yaklaşmaktaydı. Bir yandan da 'Charlotte, Charlotte, Charlotte' diye bağırıyordu. Charlotte ile Shannon ise konuşmağa dalmışlar, hiçbir şeyin farkında değillerdi. Zavallı genç kız, sevdiği erkeğe, bütün açık kalpliliğiyle, en temiz duygularıyla içini döküyor, ona kuvvet vermek, onu mutlu kılmak istiyordu. Yalvarıordu. Ne olurdu sanki Shannon, bu genç kıza bir firsat verse de o da ona istediği türlü yardım edebilse. Belki de bu küçük kız, onu mutlu kılabilirdi... Belki onun iç dünyasını değiştirebilir, ona aşkın ne olduğunu öğretebilirdi ama erkek diretiyordu. Onun için 'hayır' dendi mi hayırdı. Ne yazık ki Shannon kızın bu yalvarmaları karşısında tek bir cümleyle onun tutunmak istediği her dalı kesmeğe çabaliyordu.

"Aciz bir insan diğer bir acize yardım edemez." (64-65)

("Larry, let me help you. Please."

Miss Fellowes was approaching. She was also shouting: 'Charlotte, Charlotte, Charlotte.' But Charlotte and Shannon were talking, unaware of what was happening. Poor young girl wanted to empower him, make him happy, pouring her heart out to her beloved with an open heart and her purest emotions... Maybe she could change the man's inner world, teach him what love was but he was resisting. For him 'no' was no. Unfortunately, Shannon was trying to block off all the ways the girl was attempting to follow with a single sentence.

"The helpless can't help the helpless.")

The dialogue shown in table 2 includes only one stage direction: "approaching." It is seen that İnce does not add any further stage directions. In Unan's translation, Charlotte's feelings towards Shannon, whom she made love to in the previous act of the play, are explained in detail. In the source text, her teacher, Miss Fellowes, does not approve what is happening between them. Based on this disapproval, in her translation, Unan interprets 
transLogos 2019 Vol 2 Issue 2

Alimen, Nilüfer, and Taha Akdağ, pp. 159-179

Translation of Tennesse Williams's

A Translation Studies Journal

The Night of the Iguana as a Novel and as a

Play: A Descriptive Study

(c) Diye Global Communications diye.com.tr|diye@diye.com.tr

Shannon's answer “The helpless can't help the helpless!" as his attempt at making her give up on this romance, and she adds sentences to emphasize his reluctance and Charlotte's desperation which are absent in the source text.

Typically, novels are longer than plays. As David Ball (1983) suggests, playwrights do not give details about the characters and leave them "blank to accommodate the nature of the actor" and make casting process easier (61), which makes plays shorter. In conclusion, it could be said that Unan, by filling the gap mentioned by Ball, aims at helping the reader both visualize the scene and grasp character's inner thoughts and feelings and therefore provides additional information in her translation.

\subsection{Omissions}

Table 3 shows an example of omission strategy employed by Unan, the particular excerpt from the source text and its translation by İnce.

Table 3. Omissions in Iguana Gecesi- 1

\section{ST - The Night of the Iguana (Author: Williams, 1962)}

The light has been gradually, steadily dimming during the incident of the iguana's escape. There is, in effect, a division of scenes here, though it is accomplished without a blackout or curtain. (61)

\section{TT 1 - İguananın Gecesi (Translator: İnce, 1990)}

Iguananın kaçışı sırasında 1şık yavaş yavaş gittikçe azalmaktaydı. Burada, gerçekte herhangi bir karartma ya da perde olmadığı halde, aslında bir sahne bölünmesi vardır. (67)

(During the escape of the iguana, the light has been gradually, steadily dimming. Here, although there is no actual blackout or curtain, there is indeed a division of scenes.)

TT 2 - Iguana Gecesi (Translator: Unan, 1966)

In table 3, a stage direction on lighting is given in order to accomplish a division of scenes. The terms commonly used in theatre texts such as "scene," "light" and "curtain" are preserved in İnce's translation, which makes sense considering that there is no shift of genre. However, not only these terms but the entire stage direction is omitted in Unan's translation. 
transLogos 2019 Vol 2 Issue 2

Alimen, Nilüfer, and Taha Akdağ, pp. 159-179

Translation of Tennesse Williams's

A Translation Studies Journal

The Night of the Iguana as a Novel and as a

Play: A Descriptive Study

(C) Diye Global Communications diye.com.tr|diye@diye.com.tr

Table 4. Omissions in Iguana Gecesi-2

\section{ST - The Night of the Iguana (Author: Williams, 1962)}

Then nothing is visible but these reaching-out hands. A pure white flash of lightning reveals Hannah and Nonno against the wall, behind Shannon, and the electric globe suspended from the roof goes out, the power extinguished by the storm. A clear shaft of light stays on Shannon's reaching-out hands till the stage curtain has fallen, slowly. (78)

\section{TT 1 - İgananın Gecesi (Translator: İnce, 1990)}

O sırada bu uzanan eller dişında hiçbir şey görünmez. Bembeyaz bir şimşek parıltısı SHANNON'un arkasında HANNAH ile NONNO'yu aydınlatır, tavandan sarkan küre 1şık söner, firtına elektrik sigortasını attırmıştır. Perde yavaş yavaş ininceye kadar parlak spot ışı̆̆ 1 , uzanmış eller üzerinde kalır. (84)

(Meanwhile, nothing is seen except for the hands reaching out. A pure white flash of lightning illuminates HANNAH and NONNO behind SHANNON, the electric globe suspended from the roof goes out, the storm has blown the fuse. A clear shaft of light stays on the hands reaching out until the curtain falls slowly.)

\section{TT 2 - Iguana Gecesi (Translator: Unan, 1966)}

O sırada veranda şimşek 1şığı ile beyazlandı. Hannah ile Nonno duvara dayanmışlardı, Shannon ise ellerini öne doğru uzatmış, verandanın kenarında duruyordu. (95)

(Meanwhile, the lightning flash illuminated the porch. Hannah and Nonno had leant against the wall. Shannon stayed on the edge of the porch, reaching her hands out.)

The stage direction in table 4 is at the end of the second act. The terms "light," "stage," "curtain" are not omitted in İnce's translation, as also seen in the previous example. In the source text, the power goes out when the lightning strikes. The only thing visible to the audience is the hands of characters, reaching out to each other. However, in Unan's translation, the power cut and the stage directions regarding lighting are omitted.

\subsection{Transformation of Tense}

Williams uses simple present tense in the source text in stage directions, and İnce also prefers it. On the other hand, Unan narrates the story in the past tense. An example of transformation of tense strategy employed by Unan is shown in table 5. 
transLogos 2019 Vol 2 Issue 2

Alimen, Nilüfer, and Taha Akdağ, pp. 159-179

Translation of Tennesse Williams's

A Translation Studies Journal

The Night of the Iguana as a Novel and as a

Play: A Descriptive Study

(c) Diye Global Communications diye.com.tr|diye@diye.com.tr

Table 5. Transformation of tense in Iguana Gecesi

\section{ST - The Night of the Iguana (Author: Williams, 1962)}

Shannon goes down the two steps from the verandah with the machete. He crouches beside the cactus that hides the iguana and cuts the rope with a quick, hard stroke of the machete. (123).

\section{TT 1 - İguananın Gecesi (Translator: İnce, 1990)}

SHANNON bıçağıyla verandanın iki basamağından aşağı iner. İguanayı saklayan kaktüsün dibine diz çöküp, sert, hızlı bir darbeyle ipi keser. (128)

(Shannon goes down the two steps from the porch with her knife. He kneels down beside the cactus that hides the iguana and cuts the rope with a quick, hard stroke of the knife.)

\section{TT 2 - Iguana Gecesi (Translator: Unan, 1966)}

Shannon elindeki kocaman bıçakla aşağı indi. Iguanın [sic] bağlı olduğu kaktüs ağacının yanına çömeldi ve kuvvetli bir bıçak darbesiyle, hayvanı serbest bıraktı. O artık hürdü. Kaçabilirdi. Alışkın olduğu çimenlerin, yeşilliklerin içine koşabilirdi. (150)

(Shannon went downstairs with a big knife in his hand. He kneeled down beside the cactus tree to which the iguana was tied and released the animal. Now it was free. It would have run away. It would have run into the grass, the meadow it was familiar with.)

The above stage direction from the source text is in simple present tense. Ince also uses simple present tense in her translation while Unan uses past tense. Stage directions in plays are generally written in present tense (cf. Werth 1999, 221). However, as John Harvey (2006) underlines, many of the novels are written in past tense though the number of novels written in present tense has increased significantly in the twentieth century (74). Unlike play, which "relates the present," novel "presents a collation of human experience which was-not is," as stated by John Perry (1968) in the context of "adapting a novel to the stage," which is also an intergenre translation the other way around (i.e., from novel into a play) (1315). It could be concluded that Unan prefers to use simple past tense instead of simple present to conform to this norm, which is dominantly preferred in this literary genre, and to present Williams' work as a novel to the target reader.

\section{Discussion and Conclusion}

When the research objects in the present study are analyzed, it is seen that there are several additions in Unan's translation while İnce's translation does not involve any 
transLogos 2019 Vol 2 Issue 2

Alimen, Nilüfer, and Taha Akdağ, pp. 159-179

Translation of Tennesse Williams's

A Translation Studies Journa

The Night of the Iguana as a Novel and as a

Play: A Descriptive Study

(c) Diye Global Communications diye.com.tr|diye@diye.com.tr

noticeable changes regarding additions. Unan's aim for employing these strategies might have been to attract the readers to the text more. These additions are mostly used to express or overstate the character's feelings or the feeling that will emerge from the case in the text. She sometimes puts herself in the characters' place and makes these additions to describe their feelings. By adding some strongly emotional sentences, she also dramatizes the situations in the source text.

It might be argued that the genre difference between the source text and the target text could be the reason for these additions made by Unan. The source text includes stage directions. However, no stage direction is needed in novels, and since Unan translates the source text as a novel, these additions may be derived from the features of the novel as a genre. Playwrights provide extra-linguistic features of a theatre text through stage directions, but novelists must provide that setting verbally in their texts. Norman Page (1988) explains that novels are "likely to be more heavily burdened with informative and suggestive detail" (9). Another feature of the novels which might be the reason for these additions is their narrative nature. There is an obvious narrator in a novel who acts "as a mediating agent between the author and the reader" (Weber 1990, 101). The narrator here is not someone else but the novelist. The novelist provides the background information and possibly some kind of interpretation of the case to the reader (Link 1980, 24). Therefore, it is possible to assert that Unan acts as a translator, as a novelist and also as a narrator in her translation process.

When the omission strategy is considered, it is seen that İnce omits just a few of the stage directions. However, Unan's translation lacks the stage directions in the source text, and most of them are theatre terms. The reason for these omissions is the same as the one for the additions - as it is a case of intergenre translation.

The last strategy examined in the study is transformation of tense. The stage directions in the source text are in present tense, as seen in most of the theatre texts. The stage directions in İnce's translation are also in present tense. However, Unan prefers mostly past tense in her translation. This strategy can also be explained by the shift of genre between the two texts. Narrators transfer the information in a novel by acting as if they witnessed the story and tell it to the reader. As previously stated, Unan acts as a narrator in her translation, and thus instead of present tense, past tense is used predominantly in Iguana Gecesi (1966). 
transLogos 2019 Vol 2 Issue 2

Alimen, Nilüfer, and Taha Akdağ, pp. 159-179

Translation of Tennesse Williams's

trans Dogos

A Translation Studies Journal

The Night of the Iguana as a Novel and as a

Play: A Descriptive Study

(C) Diye Global Communications diye.com.tr|diye@diye.com.tr

Skopos Theory would be useful to interpret this discussion. Hans J. Vermeer (1996) borrows the Greek word skopos, which means "purpose, aim, goal, finality, objective; intention" (4). Each translation process is an act, and each act has an aim. Each text also has a purpose because writing is an act. In translation process, translators make decisions concerning their objectives, and these objectives do not have to be the same as those of the writer of the source text. In "Skopos and Commission in Translational Action," Vermeer states:

The source text does not determine the variety of the target text, nor does the text variety determine ipso facto the form of the target text (the text variety does not determine the skopos, either); rather, it is the skopos of the translation that also determines the appropriate text variety. $(2000,232)$

In light of this theoretical view, it can be said that the skopos of Williams for The Night of the Iguana is to produce a play. The same can be said for the skopos of Ince's translation, which is to translate a play as a play. However, the skopos of Unan's translation is different from them for she translated the play as a novel. Therefore, the different translation strategies employed by the translators in translating the same source text can be explained by the different skopoi of each translation. Precisely at this point, the socio-historical context, especially publishing sector's activities in the 1960s, should be discussed to interpret the shift of genre and the skopos of Unan and the publishing house.

In the 1960s, both the number and variety of the books published by the private publishing houses increased (cf. Berk 1999, 196). Altın Kitaplar is among the publishing houses that were publishing translations of popular literary works in the 1960s. Assuming that the private publishing houses were mainly focused on selling a high number of books and considering that the publishing market was highly competitive in the mentioned decade, one might conclude that the primary purpose was to publish books which would attract the reader's attention. This might be related to the fact that the publishing house (i.e., Altın Kitaplar) prioritized "economic capital" over "symbolic capital," which has been argued to be a priority of some publishing houses in publishing translations of theatre texts (cf. Haleva 2011, 333). As seen in the paratextual elements of Iguana Gecesi (1966) by Unan, it is underlined that the author is "powerful," and the book is "a masterpiece." The film adaptation is mentioned both in the title page and the preface, as if to 'prove' that the book is 'worth reading,' since it is adapted into a film. Considering the popularity of the film adaptations of 
transLogos 2019 Vol 2 Issue 2

Alimen, Nilüfer, and Taha Akdağ, pp. 159-179

Translation of Tennesse Williams's

Williams's works and Genette's claim that novels usually sell more than other literary genres (1997, 97), it might be asserted that Altın Kitaplar emphasizes the film adaptations and chooses not to disclose that the source text is a play. However, Can Yayınları published Iguananin Gecesi in 1990, in a year the popularity of the film adaptations of Williams's works was no longer in question. This is also consistent with the claim made by Ceyda Özmen (2010), who conducted a study on translated popular cinema novels focusing on the period from 1940 to $1960^{10}$ in Turkey. Özmen argues that "being well aware of the popularity of the foreign films among the people at the time, the publishers wanted to capitalize on the ready-made audience” (211). In Özmen's study, Altın Kitaplar was also listed among the publishing houses which "capitalize on the films in various ways" (220). Drawing on the case study, the author further argues that

[t]here became two different transfer operations during the translation process: from movie/script to novel and from source language to target language. The translators played an active role in these processes. They really did act like the authors of the novels in the way that they created another text in another format in Turkish. They took many liberties in making sure that their works were read as a 'cinema novel' by Turkish readers. Opting for a vast number of manipulations - such as additions and omissions, the translators reorganized and restructured their sources and contributed to the development of a new genre-cinema novel - in the target literary repertoire. (212)

The results of the analysis of the unique case analyzed in the present study suggest that the different translation strategies deployed in the Turkish translations stemmed from the fact that genre was shifted in one of the translations while it remained same in the other. Thus, the different strategies used in the two Turkish translations might be explained through the two different skopoi as manifest in the above-analyzed decisions made by the translators. The case scrutinized in the present study further illustrates how agents of translation might take the liberty of specifying their own translation skopos (cf. Tellioğlu 2018) under the shaping influence of socio-historical, cultural and even economic circumstances of the target literary system.

\footnotetext{
${ }^{10}$ For a detailed study on translation activity in Turkey between 1923 and 1960, see Tahir-Gürçağlar 2008.
} 
transLogos 2019 Vol 2 Issue 2

Alimen, Nilüfer, and Taha Akdağ, pp. 159-179

Translation of Tennesse Williams's

\section{References}

Akdağ, Taha. 2019. "Analysis of Two Translations in Different Literary Genres of the Play The Night of the Iguana by Tennessee Williams." Master's thesis, Istanbul 29 May1s University.

Aksoy, Berrin. 2002. Geçmişten Günümüze Yazın Çevirisi [Literary translation from past to present]. Istanbul: İmge.

Ball, David. 1983. Backwards and Forwards: A Technical Manual for Reading Plays. Carbondale: Southern Illinois University Press.

Bassnett-McGuire, Susan. 2014. "Ways through the Labyrinth: Strategies and Methods for Translating Theatre Texts." In The Manipulation of Literature: Studies in Literary Translation, edited by Theo Hermans, 87-102. New York: Routledge.

Bassnett, Susan. 1991. "Translating for the Theatre: The Case against Performability." TTR: Traduction, Terminologie, Rédaction 4 (1): 99-111. doi:10.7202/037084ar.

1998. "Still Trapped in the Labyrinth: Further Reflections on Translation and Theatre." In Constructing Cultures: Essays on Literary Translation, edited by Susan Bassnett and André Lefevere, 90-108. Clevedon: Cromwell Press.

Beerbohm, Max, Aylmer Maude, and Bernard Shaw. 1961. "Translating Drama: A Saturday Review Debate." The Shaw Review 4 (1): 2-10. https://www.jstor.org/stable/40682383.

Berk, Özlem. 1999. "Translation and Westernisation in Turkey (from the 1840s to the 1980s)." PhD diss., University of Warwick.

Bulut, Sibel. 2015. "Romandan Piyese Bir Uyarlama Örneği Olarak Çalıkuşu." [Adaptation of a novel to a play: The case of Çalıkuşu.] Turkish Studies 10 (16): 387-402. doi:10.7827/TurkishStudies.8786.

—. 2016. "Türk Tiyatrosunda Uyarlama (1860-1923)." [Adaptation in Turkish theatre (1860-1923).] PhD diss., Hacettepe University.

Demirkol, Neslihan. 2006. "Can Yücel'in Shakespeare Çevirilerinde 'Sadakat." ["Loyalty" in Can Yücel's Shakespeare translations.] PhD diss., Bilkent University.

Genette, Gérard. 1997. Paratexts: Thresholds of Interpretation. Translated by Jane E. Lewin. Cambridge: Cambridge University Press.

Haleva, Beki. 2011. "Tiyatro Çevirisi Bağlamında Bernard-Marie Koltès Oyunlarının Türkiye'deki Dolaşımı.” [Circulation of Bernard-Marie Koltès' dramas in Turkey as a part of drama translation.] PhD diss., Yildız Technical University. 
transLogos 2019 Vol 2 Issue 2

Alimen, Nilüfer, and Taha Akdağ, pp. 159-179

Translation of Tennesse Williams's

Harvey, John. 2006. "Fiction in the Present Tense." Textual Practice 20 (1): 71-98. doi:10.1080/09502360600559795.

Jakobson, Roman. (1959) 2004. "On Linguistic Aspects of Translation.” In The Translation Studies Reader, edited by Lawrence Venuti, 113-118. London: Routledge. PDF ebook.

Karantay, Suat. 1988. "Tiyatro Çevirisinin Sorunları.” [Problems of theatre translation.] Metis Çeviri, no. 2, 78-88.

. 1995. "Tiyatro Çevirisi: Oyun Dili ve Çeviri." [Theatre translation: Language of the play and translation.] In Çeviri ve Çeviri Kuramı Üstüne Söylemler [Discourses on translation and translation theory], edited by Mehmet Rifat, 93-118. Istanbul: Düzlem.

Link, Franz H. 1980. "Translation, Adaptation and Interpretation of Dramatic Texts." In The Languages of Theatre: Problems in the Translation and Transposition of Drama, edited by Ortrun Zuber, 24-50. Oxford: Pergamon Press.

Loffredo, Eugenia, and Manuela Perteghella, eds. 2009. One Poem in Search of a Translator: Rewriting 'Les Fenêtres' by Apollinaire. Bern: Peter Lang.

Maral, Nurdan, 2010. "Tiyatro Metin Çevirilerinde Çeviri Sorunları.” [Translation problems in translations of theatre texts.] Master's thesis, Dokuz Eylül University.

Meyer, Stephen C. 2009. "Illustrating Transcendence: Parsifal, Franz Stassen, and the Leitmotif." The Musical Quarterly 92 (1-2): 9-32. doi:10.1093/musqtl/gdp013.

Minutella, Vincenza. 2013. Reclaiming Romeo and Juliet: Italian Translations for Page, Stage and Screen. Amsterdam: Rodopi.

Özmen, Ceyda. 2010. "From Movie/Script to Novel: Translated Popular Cinema Novels in Turkey from 1944 to 1957.” Master's thesis, Dokuz Eylül University.

Page, Norman. 1988. Speech in the English Novel. Houndmills: Palgrave Macmillan.

Pavis, Patrice. 1989. "Problems of Translation for the Stage: Interculturalism and PostModern Theatre." Translated by Loren Kruger. In The Play out of Context: Transferring Plays from Culture to Culture, edited by Hanna Scolnicov and Peter Holland, 25-44. Cambridge: Cambridge University Press.

- 2005 "Toward Specifying Theatre Translation." Chap. 6 in Theatre at the Crossroads of Culture. Translated by Loren Kruger. London: Routledge.

Perry, John. 1968. “Adapting a Novel to the Stage.” The English Journal 57 (9): 1312-1315. doi: $10.2307 / 812138$. 
transLogos 2019 Vol 2 Issue 2

Alimen, Nilüfer, and Taha Akdağ, pp. 159-179

Translation of Tennesse Williams's

Sionis, Claude. 2000. "Intermodal and Inter-Genre Translation in Scientific Writing." $A S p$ [Online], no. 27-30. doi:10.4000/asp.2112.

Tahir-Gürçağlar, Şehnaz. 2008. The Politics and Poetics of Translation in Turkey, 1923-1960. Amsterdam: Rodopi.

Tellioğlu, Banu. 2018. "Şiir Çevirisi Eleştirisinde Çevrilebilirlik/Çevrilemezlik İkiliğini Aşmak." [Overcoming the dichotomy of translatability and untranslatability in poetry translation criticism.] RumeliDE Journal of Language and Literature Studies, no. 11, 192-213. doi:10.29000/rumelide.417493.

Topçu, Hayrunisa. 2017. "Romandan Tiyatroya: Değirmen-Sarıpınar 1914." [From novel to theatre: Değirmen-Sarıpınar 1914.] Journal of History Culture and Art Research 6 (4): 960-979. doi:10.7596/taksad.v6i4.1046.

Vermeer, Hans J. 1996. A Skopos Theory of Translation: Some Arguments for and against. Heidelberg: TEXTconTEXT.

2000. "Skopos and Commission in Translational Action." Translated by Andrew Chesterman. In The Translation Studies Reader, edited by Lawrence Venuti, 221-232. London: Routledge.

Vural Kara, Sergül, and Erdinç Aslan. 2015. "Moliere'in L'Avare Eseri Işı̆̆ıında Tiyatro Metinleri Çevirilerinin Dil Kullanımları Açısından Değerlendirilmesi." [Evaluation of language usage of theatre texts translations in the light of L'Avare de Moliere.] Journal of International Social Research 8 (36): 267-273. doi:10.17719/jisr.2015369506.

Weber, Markus. 1990. "Dramatic Communication and the Translation of Drama." Bulletin CILA, no. 52, 99-114. https://core.ac.uk/download/pdf/20655544.pdf.

Werth, Paul. 1999. Text Worlds: Representing Conceptual Space in Discourse. London: Longman.

Williams, Tennessee. 1962. The Night of the Iguana. New York: New Directions. 1966. Iguana Gecesi. Translated by Canset Unan. Istanbul: Altın Kitaplar. 1990. İuananın Gecesi. Translated by Ülker İnce. Istanbul: Can.

Zuber, Ortrun. 1980. "Problems of Propriety and Authenticity in Translating Modern Drama." In The Languages of Theatre: Problems in the Translation and Transposition of Drama, edited by Ortrun Zuber, 92-103. Oxford: Pergamon Press. 